\title{
Admirał Cornelis Tromp a rozwój taktyki liniowej
}

Anna Pastorek | Wojskowe Centrum Edukacji Obywatelskiej

\section{Streszczenie}

Słowa kluczowe: marynarka wojenna, taktyka, admirat, Holandia, XVII wiek

Admiral Cornelis Tromp and the development of the line-of-battle.

Abstract

Keywords:

navy, tactic, admiral, Holland, 17th century

Artykuł poświęcony jest rozwojowi taktyki walki na morzu w XVII wieku oraz jego konsekwencjom. W szczegółowy sposób omówiona została rola holenderskiego admirała Cornelisa Trompa (1629-1691) w rozwoju taktyki liniowej.

Paper presents the development of a naval tactic in the seventeenth century and its consequences. It discusses the role of Dutch admiral Cornelis Tromp (1629-1691) in development of the line-of-battle. 
Taktyka liniowa, która weszła w powszechne użycie w drugiej połowie XVII wieku, pozwoliła na wykorzystanie w pełni artylerii burtowej ówczesnych okrętów wojennych'1 Krajami przodującymi w stosowaniu tej taktyki były Anglia oraz Republika Zjednoczonych Prowincji. Państwa te rywalizowały o dominację w światowym handlu i zyski płynące z kolonii, a silna flota wojenna była gwarantem zabezpieczenia interesów handlowych. W omawianym okresie Republika Zjednoczonych Prowincji, będąca niekwestionowaną potęgą handlową, musiała odpierać ataki rosnącej w siłę Anglii. To właśnie Anglia jako pierwsza w 1653 r. wprowadziła przepisy nakazujące admirałom walkę w linii. Próby ustawienia okrętów w linii i wykorzystania ich artylerii burtowej zdarzały się w obu flotach już wcześniej. W historii Holandii w kwestiach związanych z taktyką liniową zawsze wymieniane są dwie postacie: admirałowie Maarten Harpertszoon Tromp (1598-1653) oraz Michiel Adriaenszoon de Ruyter (1607-1676). Są oni zarazem największymi bohaterami morskimi Holandii. Admirał Maarten Tromp uważany jest za twórcę taktyki liniowej, a Michiel de Ruyter za prawdziwego mistrza jej wykorzystania, odnoszącego świetne zwycięstwa nad angielską flotą, między innymi w najdłuższej bitwie epoki żagla - tzw. bitwie czterodniowej (11-14 czerwca 1666 r.). Nietrudno zauważyć, że w wyżej wymienionym opisie brakuje momentu oficjalnego wprowadzenia taktyki liniowej jako obowiązującej we flocie wojennej Republiki Zjednoczonych Prowincji. Z tym wydarzeniem związana jest postać admirała Cornelisa Trompa, który, choć uwielbiany przez marynarzy, po śmierci nie doczekał się sławy równej Maartenowi Trompowi i de Ruyterowi, a jego rola w rozwoju taktyki liniowej jest w większości holenderskich opracowań pomijana. Celem niniejszego referatu jest pokazanie wkładu, jaki wniósł admirał Cornelis Tromp w rozwój taktyki liniowej, oraz próba wyjaśnienia, dlaczego nie zajmuje on w historii takiego miejsca, jak jego ojciec Maarten Tromp i admirał Michiel de Ruyter.

Obecnie w Koninklijke Marine służy okręt Zr. Ms. ${ }^{2}$ Tromp. Jest to fregata LCT (luchtverdedigings- en commandofregat, czyli fregata obrony powietrznej i dowodzenia) typu „De Zeven Provinciën”, nosząca oznaczenie burtowe F803. Na oficjalnej stronie internetowej Koninklijke Marine można przeczytać, dlaczego okręt dostał takie imię (Zr. Ms. De Ruyter, 2014). O Zr. Ms. Tromp i jego poprzednikach noszących to imię napisano: „Okręty Królewskiej Marynarki Wojennej nazwane Tromp noszą to imię na część dwóch bohaterów morskich: Maartena Harpertszoona Trompa (1598-1653) i jego syna Cornelisa Trompa (1629-1691)". W interesującej nas kwestii taktyki liniowej o Maartenie Trompie pisano w ten sposób:

\footnotetext{
1 Taktyka liniowa zastąpiła stosowaną wcześniej taktykę roju, w której okręty atakowały przeciwnika w szyku przypominającym rój, a głównym celem było dokonanie abordażu i zajęcie wrogiej jednostki. W taktyce liniowej okręty idą jeden za drugim w swoich kilwaterach, tak manewrując, aby iść równolegle do wroga i móc atakować go swoją artylerią burtową. W miarę możliwości starano się przełamać linię wroga lub postawić "daszek nad T". Powodzenie tych manewrów prowadziło do znacznego zwiększenia strat we wrogiej flocie.

2 Zr. Ms. - hol. Zijner Majesteits (Jego Królewskiej Mości) - akronim odpowiadający brytyjskiemu skrótowi HMS bądź polskiemu ORP.
} 
Maarten Tromp jest jednym z największych bohaterów morskich kraju. Swoim wybitnym zdolnościom przywódczym i popularności wśród załóg zawdzięcza przydomek Bestevaer. Początkowo słowo Bestevaer oznaczało dziadka lub starego mężczyznę, później stało się pełną szacunku i poufałości nazwą własną. (...) Pod koniec 1639 roku Tromp odniósł swoje największe zwycięstwo nad hiszpańską flotą. W bitwie pod Duins ${ }^{3}$ dowodził holenderską flotą, w skład której wchodziły również eskadry dowodzone przez Witte de Witha i Joosta Banckerta. Tromp zastosował po raz pierwszy wymyśloną przez siebie taktykę liniową. Zamiast stosowanego powszechnie sposobu walki polegającego na rozpoczętym ostrzałem starciu okrętów jeden na jednego, a następnie abordażu, Tromp kazał płynąć okrętom w zwartej linii, w swoich kilwaterach4 ${ }^{4}$.

W przypadku Cornelisa Trompa uznałam za słuszne przedstawić cały opis jego postaci zamieszczony na stronie Koninklijke Marine.

Cornelis Tromp urodził się w 1629 roku w Rotterdamie. Był synem Maartena Harpertszoona Trompa. Nie miał jeszcze 16 lat, gdy ojciec zabrał go na swój okręt jako lejtnanta ${ }^{5}$. Cztery lata później został kapitanem. W wieku 26 lat mianowano go wiceadmirałem. W tej randze służył do 1665 roku. W tym roku miała miejsce bitwa pod Lowestoft. Podczas walki zginęła większość oficerów flagowych ${ }^{6}$. Tromp musiał przejąć dowodzenie. Po bitwie czasowo pełnił funkcję głównodowodzącego flotą. Pozbawiony dowodzenia po powrocie De Ruytera, stał się jego podwładnym. W 1673 roku brał udział w bitwach pod Schooneveld i Kijkduin? . W 1674 roku popłynął z częścią floty, bez zgody admiralicji, na Morze Śródziemne. Po tym incydencie nie otrzymał już nigdy więcej możliwości dowodzenia holenderską flotą. W 1691 roku na nowo pojawiła się możliwość służby dla Trompa: został mianowany głównodowodzącym. Przygotowano dla niego okręt flagowy, jednak Trompowi nie było już dane przejąć dowództwa. Jego zdrowie nagle bardzo się pogorszyło. 26 marca 1691 roku admirał zmarł w Rotterdamie ${ }^{8}$.

Pochodzenie imienia okrętu Zr. Ms. De Ruyter ${ }^{9}$ wyjaśniono w następujący sposób:

Zr. Ms. De Ruyter został tak nazwany na część admirała Michiela Adrianeszoona de Ruytera. (...) Był on jednym z największych bohaterów morskich Holandii i jako drugi po Maartenie Trompie został obdarzony przydomkiem Bestevaer. (...) W 1665 roku, w trakcie drugiej wojny angielsko-holenderskiej został głównodowodzącym flotą wojenną Republiki Zjednoczonych Prowincji, a jego okrętem flagowym został De Zeven Provinciën. W tej wojnie odniósł swoje największe sukcesy. W bitwie czterodniowej Holendrzy stracili tylko 4 okręty, podczas gdy Anglicy aż 17. (...) Podczas trzeciej wojny angielsko-holenderskiej pod Solebay (1672) skutecznie uderzył na angielsko-francuską flotę, która była liczniejsza i lepiej uzbrojona.

3 W polskiej i angielskiej historiografii znana jako bitwa pod Downs.

4 (Zr. Ms. Tromp, 2014), tłumaczenie autorki.

5 Lejtnant (luitenant) był jednym ze stopni oficerskich we flocie wojennej Republiki Zjednoczonych Prowincji.

6 Jest to poważne uproszczenie. Uszczegółowiając, zginęli wówczas: głównodowodzący flotą admirał Jacob van Wassenaner van Obdam oraz jego zastępca admirał Egbert Coretnaer, a także Auke Stellingwerf (zob. Mollema, 1940: 349).

7 W polskiej i angielskiej historiografii znana jako bitwa pod Texel.

8 (Zr. Ms. Tromp, 2014), tłumaczenie autorki.

9 Zr. Ms. De Ruyter, fregata LCT typu „De Zeven Provinciën”, oznaczenie burtowe F804. 
De Ruyter nie pokonał wroga, lecz zapobiegł inwazji na Holandię. Tę sztukę powtórzył jeszcze w bitwach pod Schooneveld (dwa razy) i pod Kijkduin. Dzięki tym sukcesom okrzyknięto go Ratownikiem Ojczyzny ${ }^{10}$.

Cytowane opisy dokonań Maartena Trompa, Cornelisa Trompa i Michiela de Ruytera można uznać za typowe dla holenderskiej historiografii. Zarówno w opracowaniach popularnonaukowych, jak i w większości opracowań naukowych da się zauważyć następujący schemat: Maarten Tromp - twórca taktyki liniowej (Doedens, Mulder, 1989: 86; Gent, 2000: 33; Prud'homme van Reine, 2001: 77-78), Michiel de Ruyter wybitny taktyk wygrywający liczne bitwy ${ }^{11}$. Tylko w bardzo specjalistycznych opracowaniach pojawiają się wzmianki dotyczące roli Cornelisa Trompa w rozwoju taktyki liniowej i wdrażaniu jej w holenderskiej flocie wojennej (Weber 1980: 338-339; Prud'homme van Reine 2001: 247-249, 419-420; Viet 2010: 60-62).

Istotnym elementem przejścia od innowacji, wprowadzonej przez Maartena Trompa, do powszechnego stosowania taktyki liniowej przez Michiela de Ruytera, było ustalenie przepisów nakazujących walkę w linii.

Zwycięstwo nad Hiszpanami pod Downs (hol. Diuns) było możliwe dzięki wykorzystaniu przez Holendrów całej siły artyleryjskiej okrętów w starciu poprzedzającym bitwę (starcie na Kanale La Manche ${ }^{12}$ ), podczas którego ogień artylerii burtowej ustawionych w linii holenderskich okrętów poważnie uszkodził atakujące hiszpańskie jednostki. Klęska Hiszpanów na Kanale La Manche przyczyniła się w istotny sposób do ich porażki pod Downs, minęło jednak sporo czasu, zanim Holendrzy zaczęli stosować powszechnie walkę w linii. Klęska w pierwszej wojnie angielsko-holenderskiej (1652-1654) wykazała wszystkie słabości floty wojennej Republiki Zjednoczonych Prowincji względem stworzonej przez Cromwella nowoczesnej floty angielskiej, wyposażonej w duże, dobrze uzbrojone okręty. Bolesne doświadczenia wojny stały się motorem do zreformowania floty wojennej Republiki Zjednoczonych Prowincji w różnych wymiarach jej działalności. Ważnym elementem reformy było oparcie floty wojennej jedynie na typowych okrętach wojennych i rezygnacja z wypożyczania i uzbrajania na czas wojny statków handlowych. Po reformie flota holenderska składała się, podobnie jak angielska, z dużych, dobrze uzbrojonych okrętów liniowych, obsadzonych profesjonalnymi załogami. „Nowa flota”, jak nazywano holenderską marynarkę wojenną po reformie, była idealnym narzędziem do stosowania taktyki liniowej i stawienia czoła Anglikom, którzy od 1653 r. oficjalnie stosowali taktykę liniową. Niestety, admirał Jacob van Wassenaer van Obdam, mianowany głównodowodzącym flotą holenderską po śmierci admirała Trompa w bitwie pod Ter Heijde (10 sierpnia 1653 r.), nie umiał wykorzystać atutów, jakie dawały mu nowoczesne holenderskie okręty. Nie

10 (Zr. Ms. De Ruyter, 2014), tłumaczenie autorki.

11 Fakt ten, całkiem słusznie, podkreślany jest w biografiach admirała De Ruytera począwszy od XVII w.

12 Miało to miejsce w dniach 16-18 IX 1639. Siłę artylerii okrętów ustawionych w linii admirał Maarten Tromp wykorzystał 16 września (Tromp, 1930: 37-38). 
wykorzystał także cennych doświadczeń Maartena Trompa z bitwy na Kanale La Manche ani doświadczeń z I wojny angielsko-holenderskiej, która udowodniła wyższość stosowanej wówczas powszechnie przez Anglików taktyki liniowej. Pierwsza bitwa drugiej wojny angielsko-holenderskiej (pod Lowestoft, 13 czerwca 1665 r.) zakończyła się bolesną klęską floty wojennej Republiki Zjednoczonych Prowincji, będąc jednocześnie największym zwycięstwem Anglików w trzech wojnach toczonych w XVII w. toczonym przeciwko Holendrom (Pastorek, 2014a: 77-79).

Przegrana bitwa wykazała konieczność wprowadzenia w Republice Zjednoczonych Prowincji - podobnie jak w Anglii - przepisów nakazujących walkę w linii, aby w przyszłości żaden admirał nie popełnił błędu Jacoba van Wassenaera van Obdama. Po śmierci Jacoba van Wassenaera w bitwie pod Lowestoft (zginął w eksplozji okrętu flagowego Eendracht) i wyznaczonego na jego zastępcę admirała Egberta Cortenanera (poległ na samym początku bitwy) w holenderskiej flocie powstało zamieszanie. Wówczas zimną krwią i niezwykłą odwagą wykazał się wiceadmirał Cornelis Tromp, który z kilkunastoma okrętami osłaniał odwrót holenderskiej floty, chroniąc ją przed pościgiem angielskich okrętów. Postawa młodego Trompa uniemożliwiła Anglikom wykorzystanie w pełni odniesionego w bitwie zwycięstwa (Bruijn, 1998: 112). Cornelis Tromp w wielu bitwach wykazał się męstwem i charakterystyczną dla siebie brawurą (bitwa czterodniowa 1666, Schooneveld 1673, Texel 1673), jednak to w przegranej bitwie pod Lowestoft udowodnił, że potrafi w opanowany sposób przejąć inicjatywę również w obliczu klęski, gdy zawiodło dowodzenie.

Niedługo po bitwie pod Lowestoft, po powrocie do Republiki Zjednoczonych Prowincji, Cornelis Tromp został awansowany do stopnia luitenant-admiraal (23 czerwca 1665 r.) i pełnił tymczasowo funkcję głównodowodzącego flotą. Zmuszony był jednak złożyć swój urząd, gdy z Indii Zachodnich powrócił admirał Michiel de Ruyter, wyznaczony na stanowisko głównodowodzącego przez sprawującego wówczas rządy w państwie pensjonariusza Holandii, Johana de Witta. Dokument o mianowaniu De Ruytera głównodowodzącym podpisano 11 sierpnia 1665 r., lecz w praktyce dowodzenie objął kilka dni później (Prud'homme van Reine, 2001: 247-249).

W czasie pomiędzy bitwą pod Lowestoft a faktycznym objęciem dowodzenia całą flotą przez Michiela de Ruytera miała miejsce kluczowa reforma.

W sobotę 15 sierpnia 1665 r. na okręcie De Liefde ${ }^{13}$, znajdującym się nieco na północ od wyspy Texel, po naradzie admirała Cornelisa Trompa z oficerami flagowymi i przedstawicielami Stanów Generalnych, wydano dokument noszący nazwę Resolutie en Ordre. Instrukcja ta stanowiła podstawę taktyki stosowanej przez Holendrów w najbliższych latach. Generale Instructie wydana rok później przez admirała De Ruytera była prawie identyczna $w$ treści z dokumentem z 15 sierpnia 1665 r. Zgodnie z instrukcją Resolutie en Ordre flotę holenderską podzielono na trzy eskadry ${ }^{14}$. Pierwsza

13 Okręt flagowy admirała Cornelisa Trompa.

14 Podział na trzy eskadry (kojarzony z taktyką admirała De Ruytera) nie był tak oczywisty, jak wydaje się nam obecnie. Holendrzy próbowali we wcześniejszym okresie różnych wariantów. Dla przykładu 
z nich stanowiła centrum floty (w niej miał znajdować się okręt głównodowodzącego), druga - straż przednią, a trzecia - straż tylną. Każda z eskadr miała być podzielona na trzy dywizjony. Miała także powstać czwarta eskadra - rezerwowa ${ }^{15}$. Ustalono trzy sygnały do ataku dawane za pomocą flag: pierwszy sygnał dla pierwszej eskadry (centrum floty), drugi dla pierwszej i drugiej eskadry (centrum i straży przedniej), trzeci dla wszystkich trzech eskadr naraz. W instrukcji znalazł się również opis wykonywania zwrotu całej floty przez sztag oraz opis manewrów floty płynącej bajdewindem. W Resolutie en Ordre sugerowano, aby oficerowie flagowi pozostawali ze swoimi okrętami nieco dalej od wroga ${ }^{16}$. Wiązały się z tym zawarte w instrukcji rozważania na temat różnych możliwych wariantów ustawienia floty względem wiatru i względem przeciwnika (1. Gdy wróg znajduje się na pozycji nawietrznej; 2. Gdy wróg znajduje się na pozycji zawietrznej, a flota holenderska od strony jego bakburty; 3. Gdy wróg znajduje się na zawietrznej, a flota holenderska od strony jego sterburty), tak aby możliwe było utworzenie wężowej formacji liniowej (Weber 1980: 338-339; Prud'homme van Reine 2001: 247-249; Viet 2010: 60-62). Dokument sygnował swoim nazwiskiem przewodniczący narady wojennej, admirał Cornelis Tromp, dokładając w ten sposób bardzo istotną cegiełkę do rozwoju taktyki liniowej. Dowodem na słuszność koncepcji zawartych w Resolutie en Ordre może być chociażby to, że przez wiele lat Holendrzy stosowali zawarte w nich koncepcje, odnosząc znakomite zwycięstwa na morzu.

Pozostaje pytanie, dlaczego w holenderskiej historiografii postać Cornelisa Trompa admirała, który włożył istotny wkład w rozwój i wdrażanie taktyki liniowej w holenderskiej marynarce wojennej - nie jest należycie eksponowana. Szukając odpowiedzi na postawione pytanie, należy rozpatrywać zagadnienie w szerszym kontekście, nie tylko stricte militarnym, ale także kulturowym.

Z militarnego punktu widzenia kluczowe znaczenie ma z pewnością fakt, że o ile Cornelis Tromp przyłożył się do stworzenia ważnego dokumentu, to nigdy nie dane mu było dowodzić w walce całą flotą wojenną Republiki Zjednoczonych Prowincji, przez

w bitwie pod Lowestoft admirał Jacob van Wassenaer van Obdam podzielił flotę na siedem eskadr, nie dzielonych na dywizjony (Ba 1665; Aitzema 1670: 443-444).

${ }_{15}$ Na utworzenie czwartej eskadry nalegał Johan de Witt. Oficerowie flagowi byli skłonni z niej zrezygnować. W praktyce w walce nie stosowano czwartej eskadry.

${ }_{16}$ Stąd pochodzi teoria o wężowej formacji liniowej. Linia miałaby być nierówna, żeby okręty flagowe znajdowały się nieco dalej od wroga. Miało to zapobiec sytuacji z bitwy pod Lowestoft, kiedy śmierć głównodowodzącego holenderską flotą admirała Van Wassenaera van Obdama i wyznaczonego na jego zastępcę Egberta Cortenaera doprowadziły do totalnego chaosu. W holenderskich źródłach nie ma dowodów, by wężową linię w rzeczywistości stosowano. Po pierwsze, byłoby to niepraktyczne, ponieważ utrudniałoby manewrowanie. Po drugie, w źródłach często pojawiają się informacje, że okręty flagowe jako pierwsze włączały się do gwałtownej wymiany ognia z wrogiem. Poza tym okręty flagowe niosły najwięcej dział, a odsuwanie ich na dalszy plan byłoby marnotrawstwem. Nigdy oficjalnie nie obalono tego punktu Resolutie en Ordre, jednak admirałowie najwyraźniej zdawali sobie sprawę, że jest on niewykonalny i stosowali klasyczną, prostą linię. J.C.M. Warnsinck (1930: 130-131) zwrócił również uwagę na to, że za niestosowaniem przez Holendrów wężowej formacji najlepiej świadczą angielskie źródła. Anglicy w XVII wieku wielokrotnie pisali o idealnie prostej linii holenderskich okrętów (Pastorek 2014b: 310; Weber, Foreest 1984: 12; Weber 1980: 338-339). 
co nie mógł wykazać swoich umiejętności taktycznych w wielkiej bitwie morskiej, która przyniosłaby mu nieśmiertelną sławę.

Drugi ważny aspekt to obecność wielu wybitnych oficerów flagowych we flocie holenderskiej w XVII wieku. Wśród nich szczególnie wyróżniali się Maarten Tromp i Michiel de Ruyter, którzy zdobyli miano bohaterów narodowych. Prezentowali nienaganną postawę zarówno w życiu zawodowym, jak i prywatnym, stanowiąc swoisty wzorzec osobowy XVII-wiecznego kalwinisty. S. Schama, badając XVII-wieczne społeczeństwo holenderskie, zwrócił uwagę na to, że popularność najwybitniejszych admirałów była równa chyba tylko sławie Wilhelma I Orańskiego. Holendrzy bardzo cenili popularne wówczas cnoty kalwińskie, takie jak pracowitość, odwaga, determinacja oraz bogactwo i sławę, osiągnięte dzięki posiadaniu tych cech. Wybitni admirałowie wpisywali się w ten schemat (Schama 2004: 248). Bohaterowie morscy - Maarten Tromp i Michiel de Ruyter - byli odbiciem ideałów kalwińskiej Republiki Zjednoczonych Prowincji. Dzięki ciężkiej pracy awansowali „od zera do bohatera”, wspinając się po drabinie kariery zawodowej od chłopca okrętowego do admirała głównodowodzącego flotą. Odważni, zdecydowani, kochający ojczyznę, zawsze posłuszni władzom Republiki. Choć uwielbiani przez tłumy, pozostali skromni. Ich charakterów nie zniszczyło również bogactwo, które zdobyli w trakcie swojej kariery. Holenderscy historycy Anna i Jan Romein (1973: 127), pisząc o admirale De Ruyterze jako holenderskim bohaterze narodowym, zdefiniowali jego cechy w następujący sposób: „Ten skromny żeglarz dał się poznać jako niezwyciężony, odważny, waleczny, szczery, sprawiedliwy, serdeczny, pobożny, wierny, łagodny, krótko mówiąc jako bohater, człowiek prostolinijny". Maarten Tromp i De Ruyter mogli więc stanowić wzorzec osobowy dla sobie współczesnych i potomnych. Tymczasem Cornelis Tromp był już w swoich czasach postacią kontrowersyjną. Z jednej strony charyzmatyczny dowódca, nieoszczędzający w walce siebie, swoich załóg ani okrętów, za co kochali go marynarze i sławili XVII-wieczni biografowie. Z drugiej strony oficer nie znoszący żadnej władzy nad sobą, wykazujący się niejednokrotnie niesubordynacją, popadający w konflikty zarówno z głównodowodzącym flotą de Ruyterem, jak i z władzami - Johanem we Wittem, Wilhelmem III czy duńskim królem Chrystianem V17 a także ze swoimi kolegami oficerami (Ba 1692: 336-345; Brandt, Roeper, Daalder 2007: 144-151; Prud'homme van Reine 2001: 419-421; Bruijn, 1983: 180-191). Życie prywatne Cornelisa Trompa również budziło emocje. W przeciwieństwie do swojego ojca Maartena Trompa i admirała De Ruytera, nie był człowiekiem skromnym. Przez całe życie zabiegał o sławę, obnosił się również ze swoim bogactwem i posiadaną władzą, co nie było dobrze widziane w kalwińskim społeczeństwie. Ożenił się z bardzo zamożną i nieurodziwą wdową z warstwy regentów, dzięki czemu awansował do elit społecznych, politycznych i finansowych Republiki Zjednoczonych Prowincji. Jego przypominający okręt dom na wodzie, zdobiony w środku dziełami sztuki sławiącymi jego bohaterskie czyny, był również nietypową jak na ówczesne czasy ekstrawagancją. Zadziorny charakter admirała przejawiał się nie tylko w konfliktach

17 Cornelis Tromp w latach 1676-1678 służył we flocie duńskiej (za zgodą księcia orańskiego Wilhelma III) . 
z innymi oficerami i przełożonymi, ale również w trwającym wiele lat konflikcie z sąsiadem, którego częścią były liczne procesy sądowe i wydawanie pamfletów (Hallema 1941: 210-225; Prud'homme van Reine 2001: 353-382). Te czynniki z pewnością wpłynęły na to, że nie nadawał się na przykładnego bohatera kalwińskiej Republiki Zjednoczonych Prowincji.

Na zakończenie warto wspomnieć o dającej się zauważyć w holenderskiej historiografii skłonności do podkreślania pierwszeństwa w wynalezieniu taktyki liniowej. Szczególnie wyraźnie widać to w klasycznym już opracowaniu J. C. de Jongego Geschiedenis ven het Nederlandsche Zeewezen (1859: 100). Holenderscy autorzy, co jest także widoczne w cytowanych w pierwszej części artykułu informacjach zamieszczonych na oficjalnej stronie Koninklijke Marine, skupiają się na podaniu ogólnej informacji o użyciu przez admirała Trompa taktyki liniowej w 1639 roku ${ }^{18}$. Anglicy podkreślają, nie bez słuszności, że to oni jako pierwsi wprowadzili w powszechne użycie taktykę liniową ${ }^{19}$. Widoczna w holenderskiej historiografii tendencja do podkreślania pierwszeństwa jest zapewne dalekim echem dawnej rywalizacji angielsko-holenderskiej o panowanie na morzach. Takie przedstawienie historii służy budowaniu dumy narodowej i nie jest jedynie domeną Holendrów. Podobne zjawiska widać między innymi w historiografii angielskiej dotyczącej epoki żagla. Uproszczenia, zwłaszcza w popularnonaukowym nurcie historii, zdarzają się niezwykle często. W takim ujęciu historii nie ma jednak miejsca dla Cornelisa Trompa - admirała, który przyczynił się do wydania w Republice Zjednoczonych Prowincji dokumentu wprowadzającego nakaz walki w linii. Stało się to w 1665 roku, w dwanaście lat po wprowadzeniu nakazu walki w linii we flocie angielskiej (1653). W opracowaniach naukowych należy jednak dążyć do możliwie obiektywnego przedstawiania obrazu dziejów, stąd uznałam za słuszne, by zwrócić uwagę polskiego czytelnika na kwestię pewnej wybiórczości w przedstawianiu wydarzeń dotyczących wdrażania taktyki liniowej w holenderskiej marynarce wojennej. Admirał Cornelis Tromp ze względu na swój charakter będzie zawsze przedstawiany w historiografii jako niezwykle odważny dowódca, lubujący się w walce, nieznający strachu zawadiaka. Warto jednak pamiętać, że ten - niejednokrotnie unoszący się w zapale bitewnym dowódca - wniósł istotny wkład w rozwój taktyki liniowej.

\section{Literatura}

Aitzema L. van, 1670, Saken van staet en oorlogh in ende omtrent de Vereenigde Nederlanden; beginnende met het jaer 1664 ende eyndigende met het begin van 't jaer 1666, t. 5, 's-Gravenhage: Johan Velly, Johan Tongerloo ende Jasper Doll Boeckverkopers.

\footnotetext{
18 Nie rozważają zazwyczaj takich kwestii, jak wprowadzenie regulaminów nakazujących walkę w linii, ustawienie floty wroga w trakcie walki, tego, czy wroga flota poruszała się, czy była nieruchoma, jak również czy przełamano linię wroga. Szerzej o kontrowersjach wokół wynalezienia taktyki liniowej przez admirała Maartena Trompa zob. Weber, 1980: 331-342; Boer, 1941.

19 Kluczowe znaczenie miało wydanie w Anglii dnia 29 marca $1653 \mathrm{r}$. Instructions for the better ordering of the fleet in fighting (Corbett, 1905: 92-104).
} 
Boer M. G. de, 1941, Tromp en de armada van 1639, Amsterdam: Noord-Hollandsche uitgevers maatschappij.

Brandt G., Roeper V., Daalder R., 2007, Het Leven van Michiel de Ruyter, Amsterdam: Athenaeum-Polak \& Van Gennep.

Bruijn J. R., 1998, Varend verleden. De Nederlandse oorlogsvloot in de zeventiende en achttiende eeuw, Amsterdam: Balans.

Bruijn J.R., 1983, Cornelis Tromp (1629-1691): Een niet-gewaardeerd dienaar van de heren, Tijdschrift voor Geschiedenis, t. 96, Wolters-Noordhoff, Groningen/Leiden.

Corbett J.S. (red.), 1905, Fighting Instructions. 1530-1816, London: Royal Navy Records Society.

Doedens A., Mulder L., 1989, Tromp. Het verhaal van een zeeheld, Baarn: Hollandia.

Foreest H.A. van, Weber R.E.J., 1984, De vierdaagse Zeeslag 11-14 Juni 1666, Amsterdam: Noord-Hollandsche Uit.

Gent T. van, Smith L. J. M. 2000, Zeventiende eeuwse admiralen en hun zeeslagen, Den Haag: Koninklijke Vereniging van Marineofficieren.

Hallema A., 1941, Cornelis Maartenszoon Tromp 1629-1691. Een schets van het leven en bedrijf van admiraal Tromp, 's-Gravenhage: A.A.M. Stols.

Jonge J. C. de, 1859, Geschiedenis van het Nederlandsche zeewezen, t. 2, Haarlem: Kruseman.

Leven en bedryf van den vermaarden zeeheld Cornelis Tromp, Graaf van Sylliesburg, Ridder van den Olifant, Baronnet etc., Luitenant Admiraal Generaal van Holland en Westvriesland, ondermengd met de voornaamste daaden van verscheidene andere zeehoofden, en voornaamentlijk met die van Marten Harpertsz. Tromp; benevens een naauwkeurig verhaal van der Nederlanderen en hunner Bondgenooten Oorlogen, sedert den jaare 1650. tegens verscheidene volkeren gevoerd.; voorzien met alle de noodige authentyke stukken en bewyzen, en vercierd met schoone kopere figuuren,1692, Amsterdam: Gedrukt voor den Autheur, en zijn te bekomen by Timotheus ten Hoorn, boekverkooper in de Nes, by de Brakke Grond in 't Zinnebeeld en by Jakob van Beverwyk, boekverkooper tot Haarlem.

Lijste van de Schepen composerende de Vlote van den Staet der Vereenigde Nederlanden, soo als de selve op den 23 en 24 May uit Texel in Zee gelopen, 1665, Admiraliteitscolleges Collection. 3255, Den Haag: Nationaal Archief.

Marine, www.defensie.nl/organisatie/marine, [dostęp: 30.12.2014].

Mollema J.C., 1940, Geschiedenis van Nederland ter zee, t. 2, Amsterdam: Vitg. mij. Joost van Vondel.

Pastorek A., 2014a, Lowestoft 1665, [w:] Polityka innymi środkami. Studia z dziejów wojskowości polskiej i powszechnej, red. M. Franz, W. Sługocki, J. Tomczak, K. Ziółkowski, Oświęcim: NapoleonV.

Pastorek A., 2014b, Holenderska flota wojenna 1639-1667. Organizacja i znaczenie, Zabrze-Tarnowskie Góry: INFORTeditions.

Prud'homme van Reine R., 2001, Schittering en schandaal. Biografie van Maerten en Cornelis Tromp, Amsterdam: Arbeiderspers.

Romein A., Romein J., 1973, Twórcy kultury holenderskiej, przeł. J. Hummel, J. Kajetanowicz, A.M. Komornicka, posł. T.Brzostowski, Warszawa: Państwowy Instytut Wydawniczy.

Schama S., 2004, The Embarrassment of Riches. An Interpretation of the Dutch Culture in the Golden Age, London: Harper.

Tromp M. H., 1930, The Journal of Maarten Harpertszoon Tromp. Anno 1639, oprac. C. R. Boxer, Cambridge: The University Press. 
Viet R. de, 2010, Vlootinstructies en de eerste twee oorlogen met Engeland in de zeventiende eeuw, MA thesis, thesis advisor Friedeburg prof. dr R. von, Rotterdam: Erasmus University,https://thesis.eur.nl/ pub/8166, [dostęp: 1.11.2017].

Warnsinckn J. C. M, 1930, Admiraal De Ruyter. De zeeslag op Schooneveld. Juni 1673, s'-Gravenhage: Nijhoff.

Weber R. E. J., 1980, Een beschouwing over het invoeren van de linie van bataille bij de Nederlandse oorlogsvloot 1665-1666, ,,Marineblad", t. 90.

Zr. Ms. Tromp, www.defensie.nl/organisatie/marine/inhoud/eenheden/schepen/zr-ms-tromp, [dostęp: 30.12.2014].

Zr.Ms. De Ruyter, www.defensie.nl/organisatie/marine/inhoud/eenheden/schepen/zr-ms-de-ruyter, [dostęp: 30.12.2014]. 